\title{
Development of Digital Education Game as An Alternative of Assesment Instruments in Science Learning for Junior High School Students
}

\author{
${ }^{1 s t}$ Listika Yusi Risnani \\ Biology Education Study Program,FKIP \\ Universitas Muhammadiyah Purwokerto
}

\author{
${ }^{2 n d}$ Arum adita \\ Biology Education Study Program, FKIP \\ Universitas Muhammadiyah Purwokerto
}

\begin{abstract}
Digital education game not only can be used as a teacher of learning media but also can be used as a teacher instrument in the assessment / assessment of learning. The purpose of this research is to develop and implement digital educational game product to be used as an alternative assessment instrument on science lesson in junior high school. The development research model used is ADDIE with the stages of Analisys, Design, Development \& Production, Implementation, Evaluation. In the early development stage the game's draft was validated by media and material experts. In the implementation phase, a limited trial was conducted in SMP Muhammadiyah 1 Purwokerto and SMP Negeri 1 Purwokerto. The data obtained were then analyzed using descriptive data analysis to process game quality data. The results showed that the teacher's assessment of digital game-based test instruments was in a very good range. The results of the assessment of the general quality of the game also showed good results until very well. Students give a positive response to the implementation of digital games in learning science in the classroom. The conclusion of this study is that digital education games that are prepared are feasible to be used as an alternative assessment instrument of science learning in junior high schools.
\end{abstract}

Keywords: Development, digital education games, assessment instruments

\section{INTRODUCTION}

The use of information and communication technology is one of the principles of learning in secondary schools in order to improve the efficiency and effectiveness of learning (Kemendikbud, 2013). Therefore, a teacher needs to develop the application of information and communication technology that is tailored to the situation and condition of students in an integrated, systematic, effective manner. Teachers can implement information and communication technology on learning in various forms, one of which is learning using educational games. Educational games are a form of game that has content and focuses more on learning activities developed in education and training programs (Hamari, et al., 2016). There are various types of educational games, one of which is a digital education game. Digital education games are one type and genre of games that are operated on a variety of digital equipment such as computer, console and mobile (All, et al., 2016).

Digital education games can not only be used by teachers as learning media but can also be used by teachers as instruments in conducting learning assessments / assessments. Assessment is a procedure carried out to obtain information about the level of mastery of students' knowledge and skills (Subali, 2012). Assessment as part of learning so that it must be carried out by the teacher whose results can be used as a basis for evaluating the learning programs implemented. Assessment is carried out through a measurement process by using a measuring instrument / specific instrument to explore information / data about the state of the test in this case is the student.

Assessment instruments can be designed by the teacher to measure the cognitive, affective, and psychomotor aspects of students in various forms including selected written tests, written test items, observation sheets, portfolio assessment sheets, questionnaire journal entries, projects and peer assessment. In measuring the mastery of cognitive aspects, the teacher can use the written form of test instrument either choice (multiple choice, righthand, matching) or stuffing test (short and detailed entries). The instrument to measure the mastery of the cognitive aspects used by the teacher so far has only been limited to traditional assessment instruments in the form of paper and pencil test 
instruments. Traditional instruments are relatively easier to compile but have a number of drawbacks, including most traditional tests presenting individual items that are highly decontextual to students, interfering with the learning process to gather information and not helping students to move forward, so that it can be feared to produce knowledge mastery information. invalid skills (Dicerbo, 2014).

Daily Deuteronomy, Middle Semester Examination (UTS), semester end exam (UAS) whose basis is paper and pencils test often creates pressure or stress on test participants (Permana, et al. 2016; Wardana \& Dinata, 2016). Assessment by using the instrument paper and pencil test is also at high risk the teacher makes an evaluation error for final decision making. Errors in assessment by teachers can be influenced by several factors such as errors in processing data, the influence of previous assessments, assessing expensive or cheap, the influence of external impressions, and the influence of hallo effects (Subali, 2012). One alternative in overcoming the problems that arise due to the use of instruments paper and pencil test is a computerbased test instrument.

Computer-based test instruments have similar effectiveness to paper and pencils tests. Digital education games as computer-based assessment instruments have a number of advantages when compared to the paper and pencil test instruments, including a complete and attractive display, allowing the exchange of two-way feedback between test participants and computers according to the program, resulting in faster feedback and accuracy greater, economic cost savings, especially for test participants with a large size (Noyes et al., 2008). The use of digital educational game instruments also allows other actions related to cognitive performance and perceptions, such as work time. The ability to capture process differences in learners as one of the main advantages of computer-based assessment (Carlbring et al, 2007). Research on the use of educational games as an assessment instrument has been reported by Dicerbo (2014), Shaffer et al., (2009), and Shute (2011) show that educational games are effective in measuring the aspects of cognitive, psychomotor and affective mastery, especially those related to learning persistence.

Based on preliminary studies conducted at several junior high schools in Purwokerto, both private and state schools show that science teachers in Purwokerto almost always use instrument of paper and pencil test in measuring the mastery of cognitive aspects of students. No science teacher has used alternative test instruments such as educational games. Observations also show that schools also have sufficient facilities in the form of adequate computer laboratories for students' learning activities for at least one class, including at
1 purwokerto Muhammadiyah Middle School and Purwokerto 1 Middle School. This opens the opportunity for the implementation of assessments using digital education games at the school. Therefore in this study digital education games will be developed as an alternative assessment instrument for science learning. Digital education game that will be developed is a game designed to contain a set of questions to measure students' abilities. Answers to questions can be categorized as correct answers or wrong answers using a ratio scale.

\section{METHODS}

This type of research is included in the development research with ADDIE Model with stages 1) analysis, 2) design, 3) development, 4) implementation, and 5) evaluation (Aldoobie, 2015).

Game Preparation Procedures Stages - ADDIE research stages includes:

\section{- Analysis}

The analysis was carried out on four things: analysis of students, analysis of instructional objectives, developing instructional analysis and developing indicators. Analysis of students includes experiences, abilities, skills, problems and things that are needed by students in undergoing tests. Researchers analyzed and identified the purpose of educational game design namely as an alternative assessment instrument. The author determines all important steps and all the details that are needed to achieve the goal up to setting indicators for achieving the objectives of developing assessment alternatives through digital education games

\section{- Design}

Based on the analysis, the design stage of the researcher did 1) determine the basic competencies that would be developed in a digital education game, 2) formulate the selected KD achievement indicators, 3) determine the assessment technique, 4) determine the form of assessment instruments, 4) determine the scope aspects to be assessed, and 5) making digital educational game designs

\section{- Development}

At this stage the process of making and preparing game assets is carried out, namely the components needed for making a digital game such as images (2D), animation, music, and a number of function buttons (buttons). At this stage, the preparation of the game was also carried out using "Unity" software. Games that have been compiled will be tested first by developers before being validated by experts. Educational games will be validated by experts (expert judgment) by assessment / evaluation experts and material experts.

\section{- Implementation}

This stage is done by testing the use of the game. The trial was conducted on 30-40 students in 
schools in Banyumas Regency. This activity was carried out to determine the feasibility of digital education games that were prepared as an alternative instrument of assessment on science learning

\section{- Evaluation}

This stage is an evaluation phase of the developed digital education game. Evaluation is done by using a questionnaire on teacher and student assessment of the quality of the game based on the quality, content and presentation aspects.

This research was conducted on students of class VII in Purwokerto 1 Muhammadiyah Middle School which will be held in November 2017 April 2018. Prior to the research, pre-survey was conducted, discussion with one of the seventh grade science teachers of Purwokerto 1 Muhammadiyah 1 and Purwokerto 1 Middle School was related to use of digital education games and assessment in science learning, availability of research supporting facilities and infrastructure (computer labs). Pre-survey and discussions with science teachers were also carried out to select subjects that would be raised in the assessment instruments in the form of educational games.

Data collection techniques in this study use nontest techniques (filling out questionnaires) and observation. Non-test techniques are used to determine the feasibility of digital education games developed and to determine the assessment and response of teachers and students to digital education games as an alternative instrument of science learning assessment. Observation techniques were carried out on the science learning activities to determine the implementation of assessment using games and ensure that all students who took the test gave an assessment of the games developed. The data instrument in this study uses a questionnaire. Questionnaires were used to obtain information about the feasibility of educational games as an alternative assessment instrument in science learning by assessment and evaluation experts and by material experts. In addition, questionnaires are also used to explore information related to the responses and assessments of teachers and students as educational game users. Questionnaires are arranged using a Likert scale (scale of five).

Instrument validity is the level of accuracy of an assessment instrument in providing empirical information or data in accordance with the circumstances to be measured (Subali, 2012: 107). Questionnaire as an instrument used to explore information about the feasibility of educational games by assessment / evaluation experts was validated using content validation, contract validation. The instrument to explore the response and assessment of the game by the teacher and students was validated by using the SPSS program by comparing $r$ count with $r$ table $(0.3)$ if $r$ count was greater than $r$ table then the questionnaire item was said to be valid (Sugiyono, 2010).

Reliability is the consistency or constancy of an instrument, meaning that if it is used to make repeated measurements it will produce the same results. The instrument can be said to be reliable / reliable (Subali, 2012). Reliability of item questionnaire reliability testing refer to the Cronbach's alpha value using the SPSS program compared to the Cronbach's alpha minimum value (0.6). If the Cronbach's alpha value from SPSS is greater than 0.6 , the questionnaire is reliable.

The data analysis technique used was descriptive quantitative and qualitative descriptive analysis. Quantitative descriptive technique is used to analyze the results of questionnaire data about the feasibility of educational games as an alternative assessment instrument by experts and response and assessment of educational games by teachers and students. The data analysis steps are as follows :

- Changing the results of questionnaires that are qualitative to quantitative with a Likert scale (five scale).

- Determine the average score for each item statement based on the following criteria for assessment criteria.

Table 1. Assessment criteria (Muskania, 2017)

\begin{tabular}{|l|l|}
\hline Criteria Value & Interval \\
\hline $\mathrm{Mi}+1.5 \mathrm{Sbi}<\mathrm{X}$ & Very good \\
\hline $\mathrm{Mi}+0,5 \mathrm{Sbi}<\mathrm{X} \leq \mathrm{Mi}+$ & Good \\
$1,5 \mathrm{Sbi}$ & \\
\hline $\mathrm{Mi}-0.5 \mathrm{Sbi}<\mathrm{X} \leq \mathrm{Mi}+$ & Good enough \\
$0.5 \mathrm{Sbi}$ & \\
\hline $\mathrm{Mi}-1,5 \mathrm{Sbi}<\mathrm{X} \leq \mathrm{Mi}-$ & Less good \\
$0,5 \mathrm{Sbi}$ & \\
\hline $\mathrm{X} \leq \mathrm{Mi}-0.5 \mathrm{Sbi}$ & Not good \\
\hline
\end{tabular}

Information :

$\mathrm{X}$ : average actual score

Mi: Mean ideal

Sbi: ideal standard deviation

Mi: (ideal highest score + ideal lowest score)

Sbi: (ideal highest score - ideal lowest score)

\section{RESULTS AND DISCUSSION}

Educational game titled Seeking Diamond is a customized semester 1 class VII learning game that represents science material about life organizations. The stages in this game use ADDIE (Analysis, Design, Development and Production, Implementation, Evaluation) models.

\section{Analysis}

a. Student Analysis

Students who become users of this educational game are students of class VII semester I. Students have had experience in playing games either via PC or smartphone. The games they have played 
so far range from including noneducational games and educational games. Educational games that are played are still limited to education for basic skills in calculating, speed, general knowledge, students have not experienced playing educational games developed based on basic competencies (KD).

\section{b. KD analysis and instructional} objectives

The results of instructional analysis in the form of the translation of basic competencies, namely basic 3.4 competencies become learning objectives.

Table 2. Learning Objectives and Indicators

\begin{tabular}{|c|c|}
\hline $\begin{array}{c}\text { Basic } \\
\text { competencies } \\
3.4 \\
\end{array}$ & $\begin{array}{c}\text { Instructional } \\
\text { Obejctives }\end{array}$ \\
\hline $\begin{array}{l}\text { Describe the } \\
\text { diversity in the } \\
\text { organizational } \\
\text { system of life } \\
\text { from the cell } \\
\text { level to the } \\
\text { organism, as } \\
\text { well as the } \\
\text { composition of } \\
\text { the main } \\
\text { chemical } \\
\text { constituent } \\
\text { cells. Through } \\
\text { observation, } \\
\text { students can } \\
\text { correctly state } \\
\text { the hierarchy of } \\
\text { life from the } \\
\text { cell to the } \\
\text { organism. }\end{array}$ & $\begin{array}{l}\text { - Through the } \\
\text { study of } \\
\text { literature and } \\
\text { discussion, } \\
\text { students can } \\
\text { explain the } \\
\text { concept of } \\
\text { organizational } \\
\text { life correctly } \\
\text { Through cell } \\
\text { observation, } \\
\text { students can } \\
\text { understand } \\
\text { and mention } \\
\text { parts of plant } \\
\text { and animal } \\
\text { cells correctly } \\
\text { Through the } \\
\text { activity of } \\
\text { comparing } \\
\text { prokaryotic } \\
\text { and eukaryotic } \\
\text { cells, students } \\
\text { can describe } \\
\text { the differences } \\
\text { in prokaryotic } \\
\text { and eukaryotic } \\
\text { cells correctly } \\
\text { Through the } \\
\text { activity of } \\
\text { comparing } \\
\text { animal cells } \\
\text { and plant } \\
\text { cells, students } \\
\text { can show } \\
\text { differences in } \\
\text { animal cells } \\
\text { and plant cells } \\
\text { correctly }\end{array}$ \\
\hline
\end{tabular}

c. Development of indicators

The indicators formulated to achieve the learning objectives using educational games are as follows.

Table 3. Development of Learning Indicators

\section{Indicators}

- Sort the hierarchy of life levels from the lowest level to the highest level

- Explain the concept of organizational life

- Mention the parts of plant and animal cells

- Distinguish the structure of prokaryotic and eukaryotic cells

- Distinguish animal cell structure and plant cell structure

\section{Design}

Assessment techniques in the form of multiple choice tests. The scope of aspects that will be assessed in the aspect that is assessed in the form of cognitive aspects and psychomotor aspects

\section{a. Digital educational game design}

\section{Game Overview}

- Title: Seeking Diamond

- Version: 1.0

- Platform: Website

- Genre: Educational games

- Art Concept: 2D

Game Concept: Seeking Diamond is an educational game that tells about the adventures of a junior high school student in collecting diamonds. The target of the adventure is that students collect as many diamonds as possible to win this game. To get a diamond, students must answer correctly every question related to the organizational material of life that appears throughout their adventure

\section{Development and Production}

At this stage the process of making and preparing game assets is carried out, namely the components needed for making a digital game such as images (2D), animation, music, and a number of function buttons (buttons). At this stage, the preparation of the game was also carried out using "Unity" software. Games that have been compiled have undergone a testing process first by developers before being validated by experts. The following are the results of game development. 


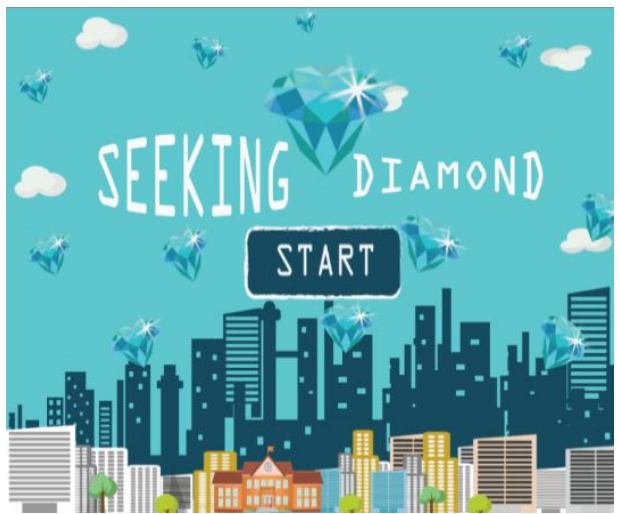

Figure 1. Display of the game
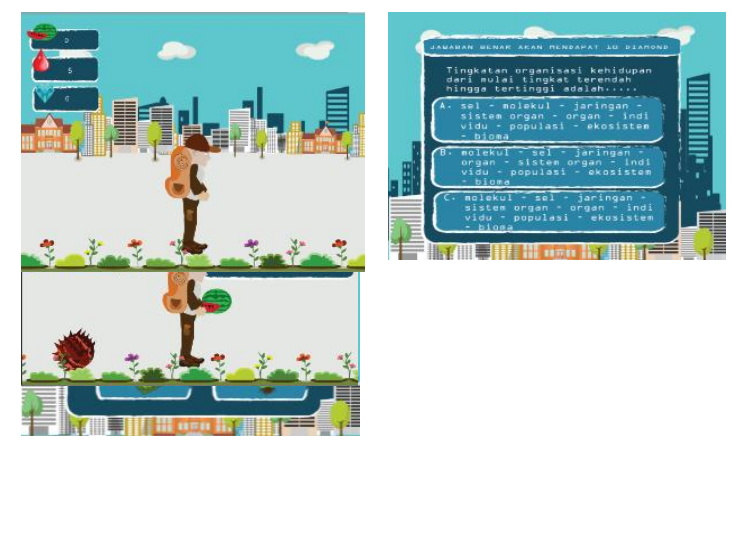

\section{Implementations}

In the implementation phase, the game was limited to two private and state schools in the city of Purwokerto, namely Purwokerto Muhammadiyah Middle School and Purwokerto 1 Middle School. The results of assessment by science teachers in the two schools which included content validity, construct validity, face validity, objectivity, and practicality of digital game-based test instruments were in the very good category (Table 4).

Table 4. Teacher Assessment of Digital Game Based Test Instruments

\begin{tabular}{|c|l|c|c|l|}
\hline No & $\begin{array}{l}\text { Component } \\
\text { Rating }\end{array}$ & $\begin{array}{c}\text { Average } \\
\text { score } \\
(\mathrm{X})\end{array}$ & Range & Criteria \\
\hline 1 & $\begin{array}{l}\text { Content } \\
\text { validity }\end{array}$ & 4,3 & $4,005<\mathrm{X}$ & $\begin{array}{l}\text { Very } \\
\text { good }\end{array}$ \\
\hline 2 & $\begin{array}{l}\text { Construct } \\
\text { validity }\end{array}$ & 4,125 & $4,005<\mathrm{X}$ & $\begin{array}{l}\text { Very } \\
\text { good }\end{array}$ \\
\hline 3 & $\begin{array}{l}\text { Face } \\
\text { validity }\end{array}$ & 3.93 & $\begin{array}{c}3,335<\mathrm{X} \leq \\
4,005\end{array}$ & Good \\
\hline 4 & Objectivity & 4.5 & $4,005<\mathrm{X}$ & $\begin{array}{l}\text { Very } \\
\text { good }\end{array}$ \\
\hline 5 & Practicality & 4.5 & $4,005<\mathrm{X}$ & $\begin{array}{l}\text { Very } \\
\text { good }\end{array}$ \\
\hline
\end{tabular}

The results also show that the results of the teacher's assessment of the quality of the game in general are as follows:
Table 6. Teacher's Assessment of the General Quality of the Game

\begin{tabular}{|l|l|c|c|l|}
\hline No & $\begin{array}{l}\text { Component } \\
\text { value }\end{array}$ & $\begin{array}{c}\text { Average } \\
\text { assessment } \\
\text { score }\end{array}$ & Range & Criteria \\
\hline 1 & $\begin{array}{l}\text { Artistic and } \\
\text { aesthetic }\end{array}$ & 3.93 & $\begin{array}{c}3,335 \\
<\mathrm{X} \leq \\
4,005\end{array}$ & Good \\
\hline 2 & $\begin{array}{l}\text { Ease of } \\
\text { Navigation }\end{array}$ & 4.2 & $\begin{array}{c}4,005 \\
<\mathrm{X}\end{array}$ & $\begin{array}{l}\text { Very } \\
\text { good }\end{array}$ \\
\hline 3 & $\begin{array}{l}\text { Overall } \\
\text { function }\end{array}$ & 4.5 & $\begin{array}{c}4,005 \\
<\mathrm{X}\end{array}$ & $\begin{array}{l}\text { Very } \\
\text { good }\end{array}$ \\
\hline
\end{tabular}

The results of a limited game trial of 49 students in two schools showed a positive response from students. The questionnaire results show that $100 \%$ of students stated that the use of educational games as a test instrument was their first experience and they stated that they were very happy with the subject matter intended by using the game. Most (88\%) students admitted that they did not feel scared and tense when they first operated the game. All students stated that the game designed as an assessment instrument made assessment of science lessons varied and dancing and $94 \%$ of students said they were happy with the way the teacher assessed science learning through games.

\section{Evalution}

Based on the results of the trial, the results were obtained very well according to the teacher and students so that it was feasible to be used as an instrument for assessing natural science. The evaluation was also carried out by exploring the responses and suggestions given by the teacher for game improvement as follows:

a. The game-based study instrument that is compiled is very interesting and is expected to be developed for further science learning 
b. How to play a game that is still monotonous so it needs to be made variations in the rules of playing games

c. Animations arranged are more varied and adapted to $\mathrm{KD}$

The results of the study are shown in Table 5 and Table 6 , the quality of the game as an instrument assessment and general assessment of the game are in a very good range. Based on these results it can be stated that the game is feasible to be used as an assessment instrument in science learning. Similar results have also been reported that game-based assessments applied to medical students to assess first aid skills gave positive results, ie no significant differences were found between the mean scores on game-based assessments and traditional tests so that gamebased assessments can provide effective for assessing student competence (Charlier, 2010).

The feasibility of the test instrument to be used is seen from the validity of the test. According to Bambang Subali (2010) and Purwanto (2010) stated that the assessment instrument was declared valid if the measuring instrument was truly able to provide empirical information in accordance with what was measured. Validity includes content validity, construct validity, and face validity has been fulfilled properly. Similar research results have also been reported on the preparation of games to assess physics learning for students at State Universities in the United States with regard to the validity of the tests (Kim \& Shute, 2015). In addition to validity, the objectivity of the test was also fulfilled well in the game because there was already a standard format to give students scores that answered correctly and the scores of students who answered incorrectly so that there would be a similarity of scores obtained by the test even though the test results were assessed by several assessors. The teacher gave a good response to the practicality of this test instrument. Practicality of tests is important to note (Purwanto, 2010). Test instruments have good practicality if the possibility of using the test is large. The practicality of the test instrument can be seen from the ease aspect as a whole the test instrument to use, the ease of interpreting / processing the test results, and the relatively low cost of administering the test.

The results of this study also showed that the implementation of the game as a test instrument received a positive response from students. $100 \%$ of students claimed to enjoy playing the game as a test instrument. This is according to Perrotta et. al., (2013) that the use of games in learning has a positive impact on increasing motivation, increasing broader knowledge and involved students in learning. The results of the same study reported that students felt very happy when applied to games in class learning (Andreas \& Casas, 2014). The results of other studies also reported that the use of digital games in learning increased the motivation and effectiveness of student learning (Papastergiou, 2009). This is presumably because students are faced with gameplay, namely topics and ideas as rules, actions, decisions, and consequences that allow students to engage with these topics and ideas through interaction and simulation, rather than through conventional test formats. Different research results were reported by Kim \& Shute (2015) that there was no significant difference in terms of pleasure for students who were given game treatment with students who were given conventional tests. This is presumably because in this study the subjects of 7 th grade students who claimed to first play games at school were related to learning so they were very happy and motivated. Games are now a popular technique used in learning including assessments in schools ranging from kindergartens to many universities (Andreas \& Cases, 2014). This can be used as a reference by the teacher to be able to consider the use of digital games as an alternative assessment in class. Games that are compiled must pay attention to the educational content therein. The purpose and assessment of the game must be in line with educational content so that the outcomes seen reflect the results of learning (Papastergiou, 2009). The game created is expected to be one of the alternative assessment instruments for science learning in SMP.

\section{CONCLUSION AND SUGGESTION} concluded:

Based on the results of the study, it can be

- Aspects that need to be considered in the preparation of digital games as an alternative assessment are instrument validity, general quality of the game, objectivity and practicality. games

- Evaluation of the validity, objectivity and practicality of the game, and the quality of the game in general are categorized as good until very well so that this game is worthy of being used as an alternative assessment instrument for science at SMP.

Based on the results of the activity analysis suggested:

- This research is limited to the development of digital games and the most has not yet arrived at the implementation in the broad field, so implementation in the field needs to be done to see more rigorous results.

- Further research is needed to assess the effectiveness of game-based test instruments with conventional test instruments. 


\section{REFERENCES}

Aldoobie, N. 2015. ADDIE Model. American International Journal of Contemporary Research, 5, 6, 68-72

All, A., Castellar, E.P.N \& Looy, J.V . 2016. Assessing the effectiveness of digital gamebased learning: Best practices. Computers \& Education, 92-93, 90-103

Andrés, M. A.A., \& Casas, M. G. 2014. Gaming in Higher Education: Students'Assesment on Game-Based Learning. Proceedings of the 45th Conference of the International Simulation and Gaming Association, 33-43

Carlbring, P., et al., 2007. Internet vs. paper and pencil administration of questionnaires commonly used in panic/agoraphobia research. Computers in Human Behavior, 23, 1421-1434

Charlier, N. 2011. Game-based assessment of first aid and resuscitation skills. Resuscitation. $82,442-446$

Colton, D. \& Covert, R. W. 2007. Designing and Constructing Instruments for Social Research and Evaluation. United States of America: John Wiley \& Sons, Inc.

Dicerbo, K. E. 2014. Game-Based Assessment of Persistence. Game-Based Assessment of Persistence. Educational Technology \& Society. 17, 1, 17-28.

Hamari, J., Shernoff, D. J., Rowe, E., Coller, B., Clarke, J. A., Edwards, T. 2014. Challenging games help students learn: An empirical study on engagement, flow and immersion in game-based learning. Computers in Human Behavior, 54, 170-179

Kemendikbud. 2013. Peraturan Menteri Pendidikan dan Kebudayaan Republik Indonesia Nomor 65 Tahun 2013 tentang Standar Proses Pendidikan Dasar dan Menengah.

Kemendikbud. 2013. Peraturan Menteri Pendidikan dan Kebudayaan Republik Indonesia Nomor 66 Tahun 2013 tentang Standar Penilaian Pendidikan.

Kim, Y. J., \& Shute, V. J. 2015. The interplay of game elements with psychometric qualities,

learning, and enjoyment in game-based assessment. Computers \& Education. 87, 340-356

Muskania, R. T. \& Wilujeng, I. 2017. Pengembangan pembelajaran Project-Based Learning untuk Membekali Foundational Knowledge dan Meningkatkan Scientific Literacy. Cakrawala Pendidikan, 36, 1, 3443

Noyes, J. M \& Garlandb, K. J. 2008. Computer- vs. paper-based tasks: Are they equivalent?. Ergonomics, 51, 9, 1352-1375
Papastergiou, M. 2009. Digital Game-Based Learning in high school Computer Science education: Impact on educational effectiveness and student motivation. Computers \& Education, 52, 1-12

Permana, H., Harahap, F., Astuti, B. 2016. Hubungan antara efikasi diri dengan kecemasan dalam menghadapi ujian pada siswa kelas IX di MTs Al Hikmah Brebes.Jurnal Hisbah, 13, 1, 51-68

Perrotta, C., Featherstone, G., Aston, H., Houghton, E. 2013. Game-based learning: latest evidence and future directions. NFER Research Programme: Innovation in Education). Slough: NFER.

Purwanto, N. 2010. Prinsip -Prinsip dan TEKNIK Evaluasi Pembelajaran. Bandung : PT. Remaja Rosdakarya

Shaffer, D. W., Hatfield, D., Svarovsky, G. N., Nash, P., Nulty, A., Bagley, E., Mislevy, R. (2009). Epistemic network analysis: A prototype for 21st-century assessment of learning. International Journal of Learning and Media, 1, 2, 33-53

Shute, V. J. (2011). Stealth assessment in computer-based games to support learning. Computer games and instruction. Charlotte, NC: Information Age Publishers.

Subali, B. 2012. Prinsip Asesmen \& Pembelajaran. Yogyakarta: UNY Press.

Sugiyono. 2010. Metode Penelitian Kuantitatif, Kualitatif dan $R \& D$. Bandung: Penerbit Alfa Beta.

Wardana, M. S., \& Dinata, I. M. 2016. Tingkat Stress Siswa Menjelang Ujian Akhir Semester di SMAN 4 Denpasar. E-JURNAL MEDIKA. 5, 9, 1-4 